https://doi.org/10.4314/rjeste.v3i2.6

\title{
Assessment of Cohesive Soil - Cow Dung Mortar Properties as Replacement of Cement Mortar for Simple Plastering Works
}

\author{
Leopold Mbereyaho ${ }^{1 *}$, Dieudonné Irafasha ${ }^{1}$, Etienne Habumugisha ${ }^{1}$, Julius Musabirema ${ }^{1}$ \\ ${ }^{1}$ Department of Civil, Environmental and Geomatics Engineering, University of Rwanda, College of Science and \\ Technology. P.O Box: 3900 Kigali, Rwanda \\ *Corresponding author: Leopold Mbereyaho, E-mail Imberevaho2015@gmail.com
}

\begin{abstract}
The development of local construction industry has resulted in the high demand for cement, used not only for structural but also non structural applications, such as finishing. As a consequence cement has been far from being an affordable material for the good part of the population, especially in the rural areas where financial means are still limited. Regarding the finishing exercise, those people have been using soil mortar alone or reinforced with grasses without any strategy about mixture content. The objective of this study was to assess the performance of cohesive soil mortar mixed with cow dung and establish recommended mix content for plastering works. Twelve samples of soil mortar with 10\%, 20\%, 30\% and 40\% of cow dung, were prepared and subjected to drying period of 28 days before they were tested for water absorption, shrinkage, weathering resistance, specific gravity and Atterberg limit tests. The tests showed good results for checked properties with $20 \%$ of cow dung, and therefore it could be considered as a low-cost alternative plastering material to cement mortar for some structural members under normal weather conditions. In order to avoid the earlier shrinkage and cracks in this mortar due to spontaneous drying by sun, the mortar should be protected and not be left in open area at earlier stage.
\end{abstract}

Keywords: Cohesive Soil, Cow dung, Mortar, Shrinkage, Water absorption, Weathering resistance

\section{INTRODUCTION}

The ever-growing local construction industry has resulted in the high demand for cement, and in its extensive manufacturing and importation, as consequences. Cement has been the most used material for both structural (concrete frame, etc) and nonstructural elements (cement plaster, etc.). The national housing policy has been promoting the use of local construction materials, while insisting on the green production process (Rwanda National Housing Policy, 2015). However, the current production of cement has been going with negative impact to the environment due to its components extraction and manufacturing process. Moreover, the high demand for cement has not helped in its cost regulation and is still not much affordable for the 
great part of the population. In many different regions in Rwanda, especially in rural areas, the building finishing is still being done using soil mortar, at least for the $1^{\text {st }}$ coat (Rwanda Housing Authority, 2012). As practice for its performance increase, the soil mortar is being mixed with either grasses, or with cow dung or both, but without following any guidance regarding the type of soil and mix proportion. The use of cow dung was discussed in different previous studies. The compression test of clayey soil bricks mixed with cow dung demonstrated that the strengths of the bricks decreased with the increase of cow dung content (Katale et al., 2014). Sometimes however, an amount of cement is added for improving the compressive strength of cow-dung stabilized earth blocks as a good solution for affordable and sustainable housing delivery (Adinkrah-Appiah and Kpamma, 2015). Regarding the mixing ratio for sandy clay soil mortar mixed with cow dung, some studies recommend the 1:4 ratio for the highest compressive strength and the highest resistance to erosion (Simango and Lyson, 2005), and in that line, the dry compressive strength of bricks stabilised with $20 \%$ cow dung content increased for about $25 \%$ over that of the plain earth brick without stabilizer (Yalley and Manu, 2013). Cow dung has also been used in mixture with other materials to form a joint stabilizer. The partial replacement of cement with fly ash and cow dung ash while using quarry dust as a fine aggregate established the maximum compressive strength at 10\% fly ash $+5 \%$ cow dung ash in 28 days (Kumar, 2018). When cement mortar with cow dung only is used, the $10 \%$ replacement of cement by cow dung ash considerably increased the compressive strength comparing with the conventional mortar (Vasu, 2019); however for some cases after 5\% the strength decreased with further increase in the cow dung ash content, and therefore that percentage for cement replacement in mortar was recommended (Kumar et al., 2015). The compressive strength of concrete made with cow dung ash and glass fibre for the M25 mix design increased up to 8\% replacement of cement by cow dung ash (Mathew et al., 2017). When cow dung and local brewery waste were used as a partial replacement of cement for plastering low cost houses it established the good potential of using cow dung and local brewery waste as a plastering material (Okello et al., 2017). Not only the replacement of cement by cow dung ash and coconut fiber would reasonably improve the properties of concrete by about $55-70 \%$, but also be economical, while also eliminating the problem of landfills, reducing the environmental risk and maintaining the ecological balance (Venkatasubramanian et al., 2012).

Even if different studies results were available, there was still lacking the clear guidance for sustainable application of cow dung in soil mortar. In line with recognition of that rural practice, the aim of this study was to assess how efficient should be the use of soil mortar prepared by mixing a well selected cohesive soil with cow dung under established and efficient mix ratios, in search of the solution to the dual problem of environment degradation and high cost of cement in construction projects. The performance of cohesive soil mortar mixed with cow dung was assessed through some tests, and the comparison with the ordinary cement mortar was then made. Among others, the study was conducted in line with the following specific objectives: to check the composition and properties of ordinary cement mortar, to establish the properties of 
cohesive soil and cow dung, to prepare a new mortar at the basis of cohesive soil and cow dung and check their properties.

\section{MATERIALS AND METHODS}

The methodology used in this study included the literature review on construction materials and others related fields for background, the visit to some construction sites in the rural areas, collection of the materials samples (cow dung and cohesive soil) and laboratory tests for analysis of soil and soil mortar properties. The following properties were tested: specific gravity test of soil Water absorption, Moisture content, Atterberg Limits (Liquid Limit \& Plastic Limit), Plasticity index, Workability test, Shrinkage test of cohesive soil mortar mixed with cow dung, Durability test for cohesive soil mortar mixed with cow dung and for cement mortar.

\subsection{Materials}

Both the cohesive soil and cow dung were collected in Kigali city. The tap water was used in all mixes. The tools used in sample collection included the wheel barrow used for transporting the collected sample from the field, the spade for mixing soil and cow dung to obtain homogeneous mix, empty bag to carry the soil and sand, the bucket and hoe to collect and carry the cow dung, and the cylindrical jar used in measuring the amount of water to be used in the mix. The following Fig. 1 and Fig. 2 show the process for collection of cohesive soil and cow dung on the field respectively.
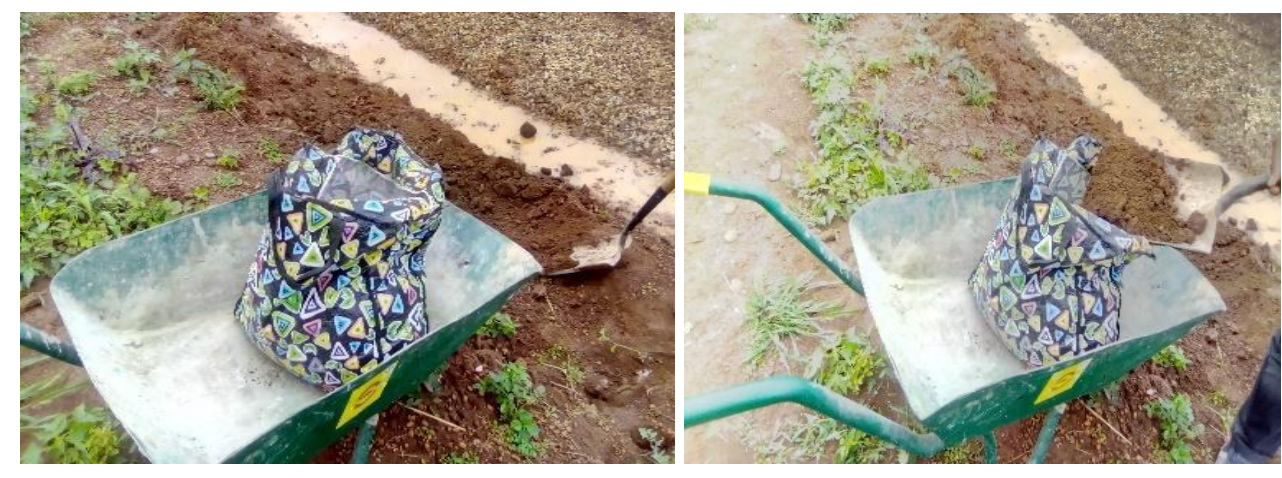

Figure 1: Collection of cohesive soil on the field 

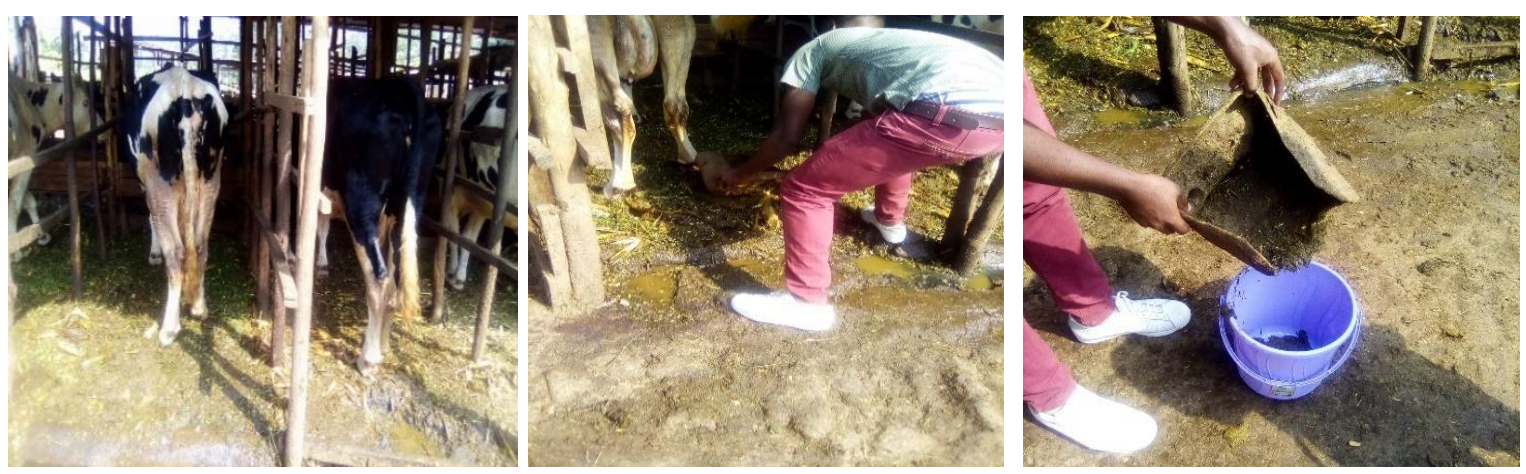

Figure 2: Collection of cow dung on the field

\subsection{Methods}

For the mortar production and cubes preparation, the soil samples were sieved so as to get a well graded soil with a sieve of $4.75 \mathrm{~mm}$ diameter. Then all samples were weighted and water was added to the wet cow dung, and then mixed thoroughly to make a uniform and a fluid paste. Then the paste was poured in the collected and sieved cohesive soil sample, while mixing thoroughly and batching to form a consistent and stiff mortar for workability. The cow dung was added in the sieved soil under following portions: 10\%, 20\%, 30\% and 40\% of mortar weight. For the test, the variable was the cow dung, while the soil quantity was constant. The Fig. 3 shows the mixing process of cohesive soil with cow dung.
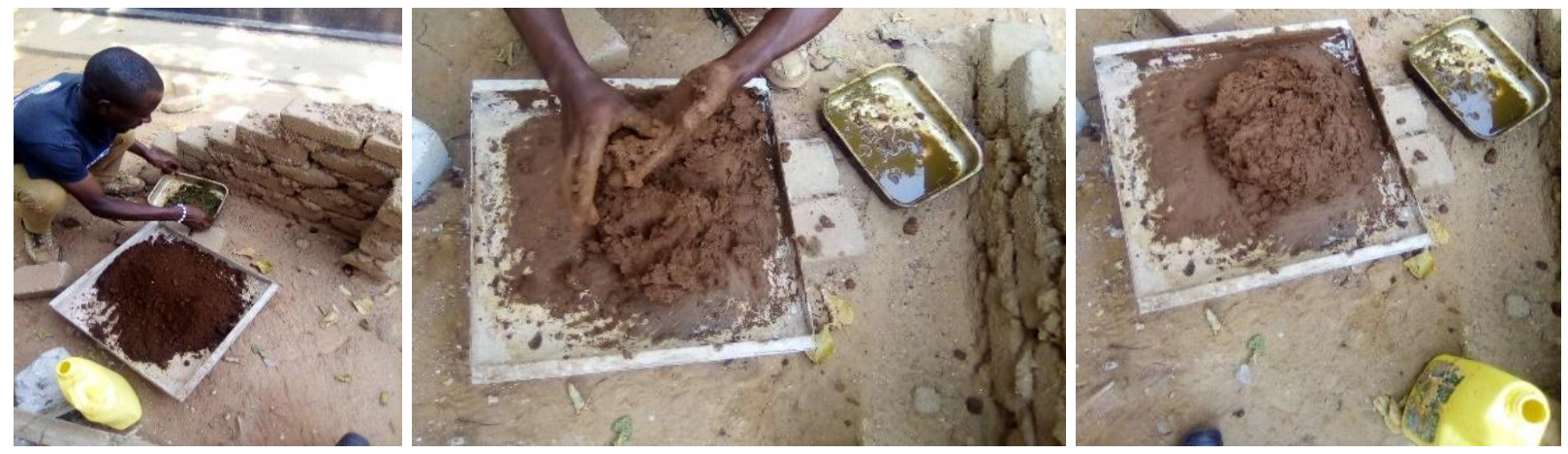

Figure 3: Mixing of cohesive soil with the cow dung

The mixture cow dung and soil was subjected to the careful volumetric batching to maintain a uniform and consistent mix. Water was gradually added until the workable mortar was achieved. As stated in this study, the mixing ratios of 1:10, 1:5, 3:10, and 2:5 of cow dung to cohesive soil was used for producing mortar. The mixing was done manually in time ranging between 34 minutes for having a good mixture and compaction were done by the use of tempering rod so as to reduce the voids and to increase the strength of the cubes (Adinkrah-Appiah, 2013). For cement mortar, the specified mixing ratio was 1:5 
The mixture was then poured into the standard metallic mould of $10 \mathrm{~cm} \times 10 \mathrm{~cm} \times 10 \mathrm{~cm}$ size, the same which is used for concrete. The mixture was then compacted manually using a metallic tamping rod, many times over one layer. The specimens were kept at room temperature up to the day of testing (28 days). The following Fig.4 and Fig.5 illustrate the cubes in the moulds and the dried cubes respectively

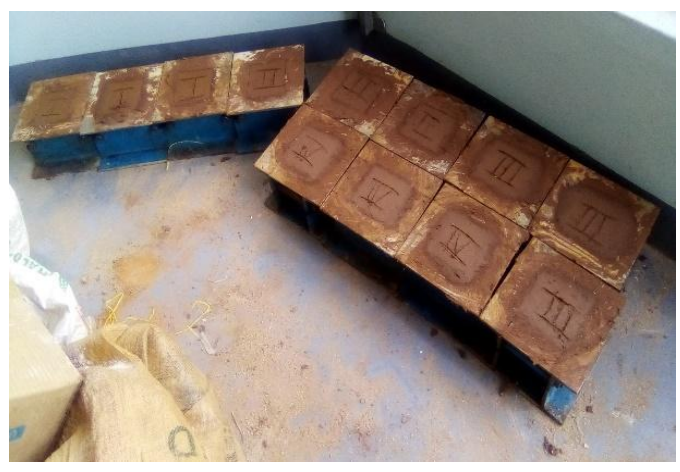

Figure 4: Cubes in the moulds

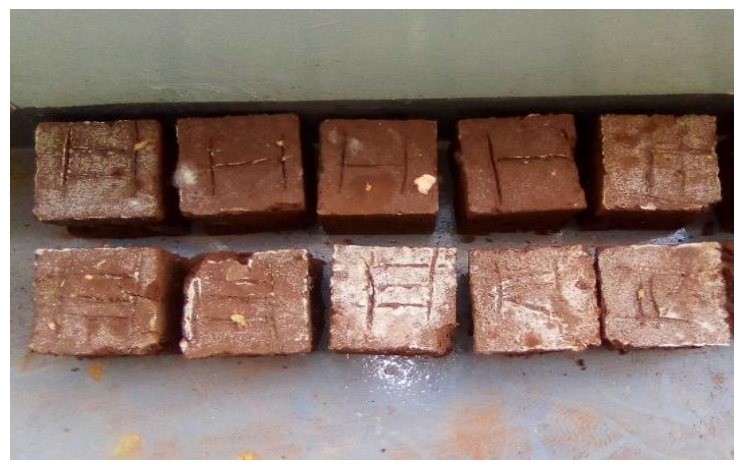

Figure 5: Dried cubes

Concerning the laboratory test, short description is presented.

Specific gravity test was conducted on the soil sample for determining the degree of saturation of the cohesive soil, and Atterberg limits test was for identifying the range of the plasticity considered as the key property of cohesive soils. Then cubes were immersed in water in order to check their water absorption so that the least water absorption is used. All tests were conducted in compliance with the specification of British standard (BS-1924:1990). Some of the used apparatus are presented in Fig. 6 below.

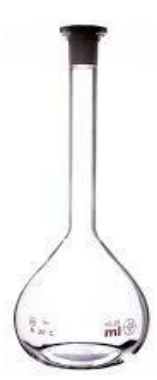

Flask

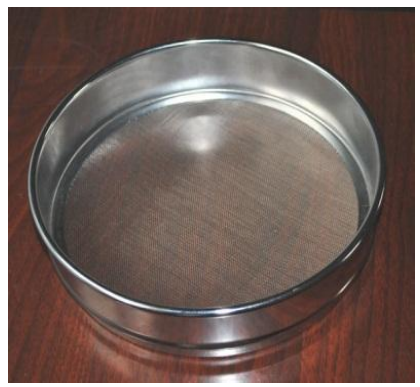

Sieve mesh of $2 \mathrm{~mm}$

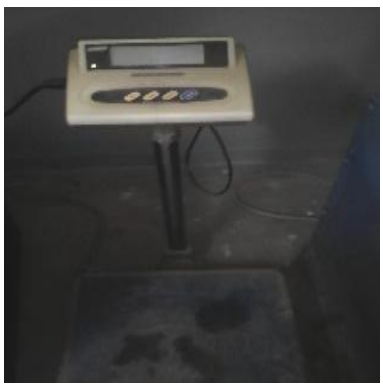

Balance

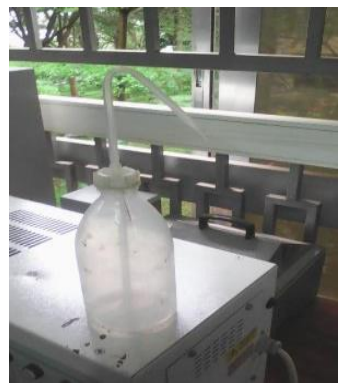

Washing bottle 


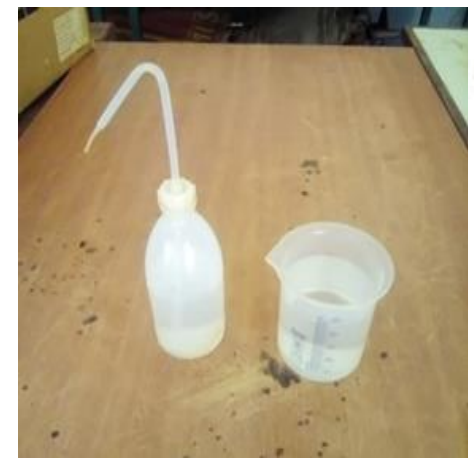

Beaker and washing bottle

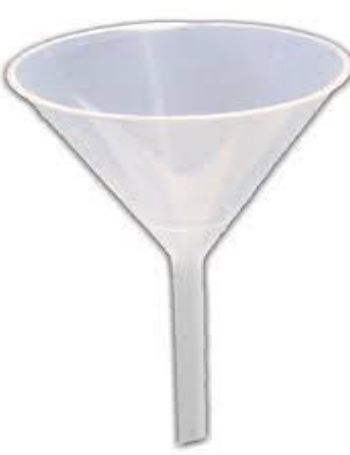

Funnel

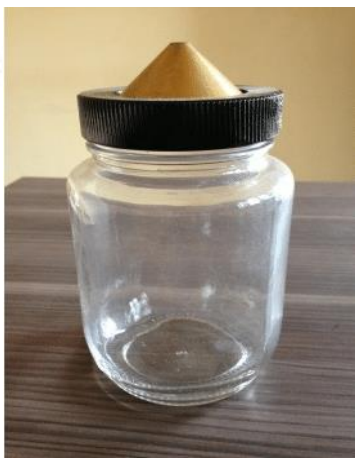

Pycnometer

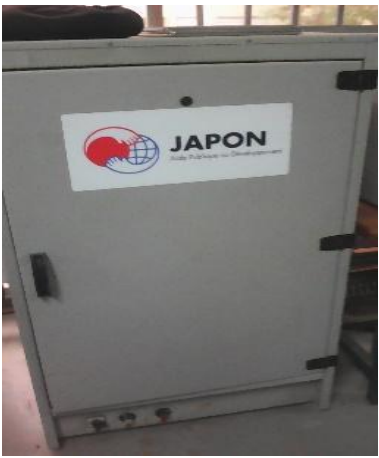

Thermostatically

Figure 6: Some used apparatus

The specific gravity was calculated using the following formula (1)

$$
G S=\frac{w 2}{W 2+(w 1-w 3)}
$$

The shrinkage was determined on the dried cubes. This test on the prepared mortar was carried out to determine the level of reduction in size of the dried cubes compared to the wet cubes. For this test, four samples were produced and composed of 12 cubes, 3 cubes for each sample with $10 \%, 20 \%, 30 \%$ and $40 \%$ cow dung.

\section{RESULTS AND DISCUSSION}

\subsection{Atterberg limits test for checking the soil cohesion}

The water content corresponding to the transition from one state to another are termed as Atterberg Limits and the tests required determining the limits are the Atterberg Limit Tests. The difference in water content between plastic and liquid limit is called the plasticity index $I_{p}\left(I_{p}=W_{L}-W_{p}\right)$. The table 1 below illustrates the liquid limit determined for the soil.

Table 1: Liquid limit determination

\begin{tabular}{|l|c|c|c|c|}
\hline Sample number & 1 & 2 & 3 & 4 \\
\hline Can number & 001 & 046 & 089 & 004 \\
\hline Mass of empty can (g) & 48.1 & 44.7 & 45.3 & 47.4 \\
\hline MCMS=Mass of can +wet soil (g) & 80.0 & 77.1 & 74.7 & 73.6 \\
\hline Mws = Mass of wet soil (g) & 31.9 & 32.4 & 29.4 & 26.2 \\
\hline MCDS=Mass of can +dry soil (g) & 70.9 & 67.8 & 66.1 & 65.9 \\
\hline MDS=Mass of dry soil (g) & 22.8 & 23.1 & 20.8 & 18.5 \\
\hline
\end{tabular}


https://doi.org/10.4314/rjeste.v3i2.6

\begin{tabular}{|l|c|c|c|c|}
\hline $\mathrm{M}_{\mathrm{w}}=$ Mass of pore water $(\mathrm{g})$ & 9.1 & 9.3 & 8.6 & 7.7 \\
\hline $\mathrm{W}=$ Water content \% & 39.91 & 40.26 & 41.35 & 41.62 \\
\hline Numbers of drops & 34 & 19 & 15 & 11 \\
\hline
\end{tabular}

From the table 1, the average liquid limit (LLav) is calculated and equal to $40.785 \%$. The table 2 below shows the soil plastic limit determination.

Table 2: Plastic limit determination

\begin{tabular}{|l|l|l|l|}
\hline Sample number & 1 & 2 & 3 \\
\hline Can number & 015 & 006 & 003 \\
\hline Mc=Mass of empty can (g) $_{\mathrm{c}=}$ & 45.3 & 48.0 & 45.0 \\
\hline $\begin{array}{l}\text { Mcws=Mass of can + Wet soil } \\
(\mathrm{g})\end{array}$ & 52.2 & 56.5 & 57.6 \\
\hline Mws = Mass of wet soil (g) & 6.9 & 8.5 & 12.6 \\
\hline McDs=Mass of can + dry soil (g) & 51.0 & 54.9 & 55.1 \\
\hline MDs=Mass of dry solid (g) & 5.7 & 6.9 & 10.1 \\
\hline M $_{\mathrm{w}=\text { Mass of pore water }(\mathrm{g})}$ & 1.2 & 1.6 & 2.5 \\
\hline Water content \% & 21.05 & 23.19 & 24.75 \\
\hline
\end{tabular}

From the table above, the average plastic limit (PLav) is calculated and found equal to 23.00\%.

Then the plasticity index $(\mathrm{PI})=$ Liquid limit $(\mathrm{LL})$ - Plastic limit $(\mathrm{PL})=\underline{\mathbf{1 7 . 7 8 5 \%}}$

The above value of plasticity index indicates that the soil was of the medium plasticity, as it should be ranging between10-20 (Burmister, 1949).

\subsection{Water absorption and shrinkage tests}

Water absorption refers to the measure by which the weight of a specimen stored for 28 days in a laboratory environment and immersed in $5 \mathrm{~mm}$ depth of water for 10 minutes increase in accordance with BS1881: part 1-1990. The mix ratio for the sample that have showed low shrinkage and without cracking was selected to be used in the production of cohesive soil mortar mixed with cow dung. The following table 3 presents water absorption results for the dried cubes removed from water after 24 hours respectively. 
Table 3: Water absorption results of the dried cubes from water after 24 hours

\begin{tabular}{|c|c|c|c|c|c|c|}
\hline \multirow{2}{*}{$\begin{array}{c}\text { Test to be } \\
\text { done }\end{array}$} & \multirow{2}{*}{$\begin{array}{l}\% \text { of } \\
\text { cow } \\
\text { dung }\end{array}$} & \multirow{2}{*}{$\begin{array}{l}\text { Mix } \\
\text { ratio } \\
(\mathrm{C}: \mathrm{S})\end{array}$} & \multirow{2}{*}{$\begin{array}{l}\text { Number } \\
\text { of } \\
\text { samples }\end{array}$} & \multicolumn{3}{|c|}{ Results } \\
\hline & & & & $\begin{array}{l}\text { Mass of dry } \\
\text { cube } \\
(\mathrm{Kg}) \\
\mathrm{W}_{1}\end{array}$ & $\begin{array}{c}\text { Mass of } \\
\text { wet cube } \\
(\mathrm{Kg}) \\
\mathrm{W}_{2}\end{array}$ & $\begin{array}{l}\% \text { Water absorption } \\
\frac{W 2-W 1}{W 1} \times 100\end{array}$ \\
\hline \multirow{12}{*}{$\begin{array}{c}\text { Water } \\
\text { absorption } \\
\text { test }\end{array}$} & \multirow[t]{3}{*}{$10 \%$} & \multirow[t]{3}{*}{$1: 10$} & 1 & 1.29 & 1.63 & \multirow[t]{3}{*}{23.25} \\
\hline & & & 2 & 1.33 & 1.55 & \\
\hline & & & 3 & 1.25 & 1.59 & \\
\hline & \multirow[t]{3}{*}{$20 \%$} & \multirow[t]{3}{*}{$1: 5$} & 1 & 1.16 & 1.39 & \multirow[t]{3}{*}{19.827} \\
\hline & & & 2 & 1.14 & 1.35 & \\
\hline & & & 3 & 1.18 & 1.43 & \\
\hline & \multirow[t]{3}{*}{$30 \%$} & \multirow[t]{3}{*}{$3: 10$} & 1 & 1.05 & 1.64 & \multirow[t]{3}{*}{56.19} \\
\hline & & & 2 & 1.01 & 1.55 & \\
\hline & & & 3 & 1.06 & 1.73 & \\
\hline & \multirow[t]{3}{*}{$40 \%$} & \multirow[t]{3}{*}{$2: 5$} & 1 & 0.95 & 1.27 & \multirow[t]{3}{*}{33.68} \\
\hline & & & 2 & 0.90 & 1.22 & \\
\hline & & & 3 & 1.0 & 1.32 & \\
\hline \multicolumn{6}{|c|}{ Number of samples cubes $(10 \mathrm{~m} \times 10 \mathrm{~m} \times 10 \mathrm{~m})=12$} & \\
\hline
\end{tabular}

The Fig.7 below gives the graphic presentation of water absorption changes in mortar in function of cow dung content

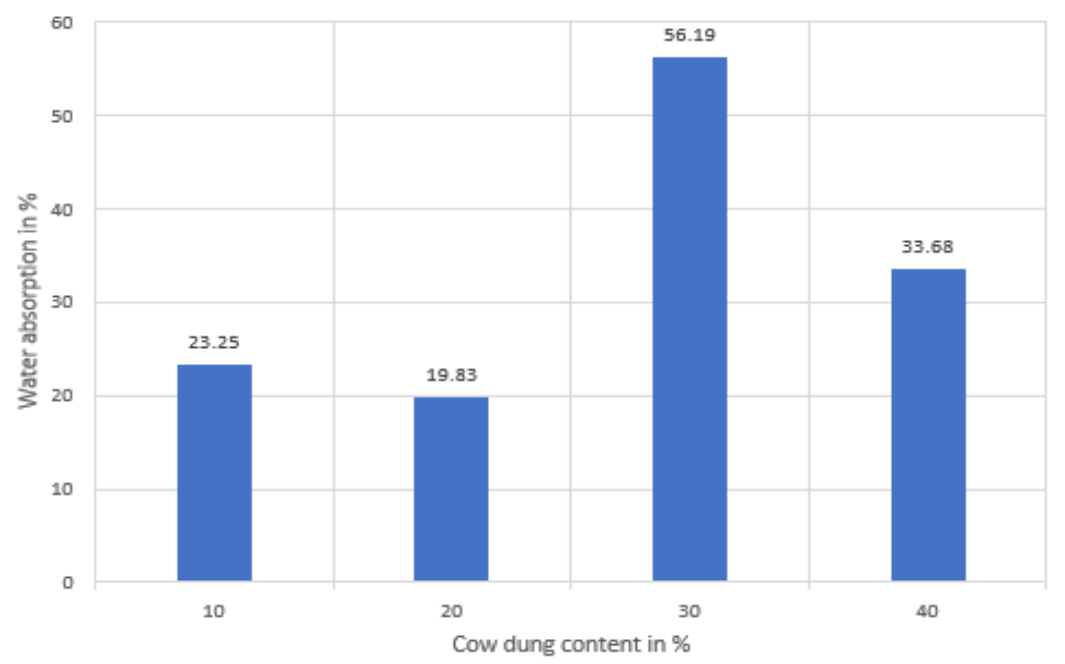

Figure 7: Water absorption of mortar in function of cow dung content 
As illustrated in the table 3 and its respective Fig. 7, the mix ratio that gives the minimum water absorption is $20 \%$ (1:5) with water absorption of $\mathbf{1 9 . 8 2}$. This value is in line with standards, and therefore the respective mix ratio will be considered for further steps.

\subsection{The specific gravity test}

The following table 4 illustrates the collected soil for specific gravity calculation.

Table 4: Collected data for specific gravity

\begin{tabular}{|c|l|l|l|}
\hline $\mathrm{S} / \mathrm{N}$ & Sample 1 & Sample2 & Sample 3 \\
\hline 1 & $\mathrm{~W} 1=673.24 \mathrm{~g}$ & $\mathrm{~W} 1=668.9 \mathrm{~g}$ & $\mathrm{~W} 1=671.4 \mathrm{~g}$ \\
\hline 2 & $\mathrm{~W} 2=50 \mathrm{~g}$ & $\mathrm{~W} 2=50 \mathrm{~g}$ & $\mathrm{~W} 2=50 \mathrm{~g}$ \\
\hline 3 & $\mathrm{~W} 3=704.7 \mathrm{~g}$ & $\mathrm{~W} 3=699.74 \mathrm{~g}$ & $\mathrm{~W} 3=701.51 \mathrm{~g}$ \\
\hline
\end{tabular}

The specific gravity (SG) was calculated using formula (1) presented in section 2 . Therefore for the sample 1, SG - 2.69; sample 2, $\mathrm{SG}=2.609$; sample $3, \mathrm{SG}=2.51$

The average specific gravity of cohesive soil sample $=(2.69+2.609+2.51) / 3=2.603$. This value is in line with standards as it should range between 2.6-2.8 (ASTM D 854-92).

\subsection{Shrinkage test for cohesive soil mortar mixed with cow dung}

The following table 5 shows the shrinkage results for the dried cubes

Table 5: Shrinkage test results

\begin{tabular}{|c|c|c|c|c|c|c|c|c|}
\hline \multirow[t]{2}{*}{ Samples } & \multicolumn{3}{|c|}{$\begin{array}{c}\text { Dimensions of cubes in } \\
\text { meter }(\mathrm{m})\end{array}$} & \multirow{2}{*}{$\begin{array}{c}\% \text { of } \\
\text { cow } \\
\text { dung } \\
\text { content }\end{array}$} & \multirow{2}{*}{$\begin{array}{l}\text { Volume } \\
\text { of dried } \\
\text { cubes }\end{array}$} & \multirow[t]{2}{*}{$\begin{array}{l}\text { Average } \\
\text { of volume }\end{array}$} & \multirow[t]{2}{*}{$\begin{array}{l}\text { Shrinkage } \\
\text { value }\end{array}$} & \multirow[t]{2}{*}{$\begin{array}{c}\% \text { of } \\
\text { shrinkage }\end{array}$} \\
\hline & Height & Length & Width & & & & & \\
\hline \multirow[t]{3}{*}{1} & 0.088 & 0.09 & 0.092 & \multirow[t]{3}{*}{10} & 0.000728 & \multirow[t]{3}{*}{0.000753} & \multirow[t]{3}{*}{0.000247} & \multirow[t]{3}{*}{24.7} \\
\hline & 0.092 & 0.092 & 0.092 & & 0.000778 & & & \\
\hline & 0.089 & 0.092 & 0.092 & & 0.000753 & & & \\
\hline \multirow[t]{3}{*}{2} & 0.09 & 0.091 & 0.092 & \multirow[t]{3}{*}{20} & 0.000753 & \multirow[t]{3}{*}{0.000747} & \multirow[t]{3}{*}{0.000253} & \multirow[t]{3}{*}{25.3} \\
\hline & 0.09 & 0.091 & 0.092 & & 0.000753 & & & \\
\hline & 0.09 & 0.091 & 0.09 & & 0.000737 & & & \\
\hline \multirow[t]{3}{*}{3} & 0.09 & 0.093 & 0.093 & \multirow[t]{3}{*}{30} & 0.000778 & \multirow[t]{3}{*}{0.000758} & \multirow[t]{3}{*}{0.000242} & \multirow[t]{3}{*}{24.2} \\
\hline & 0.09 & 0.092 & 0.091 & & 0.000753 & & & \\
\hline & 0.09 & 0.091 & 0.091 & & 0.000745 & & & \\
\hline 4 & 0.092 & 0.092 & 0.092 & 40 & 0.000778 & 0.000771 & 0.000229 & 22.9 \\
\hline
\end{tabular}




\begin{tabular}{|c|c|c|c|l|c|l|l|l|}
\hline & 0.093 & 0.093 & 0.09 & & 0.000778 & & & \\
\cline { 2 - 4 } & 0.09 & 0.091 & 0.092 & & 0.000753 & & & \\
\hline
\end{tabular}

The following Figure. 8 presents the shrinkage variation of mortar in function of the cow dung content.

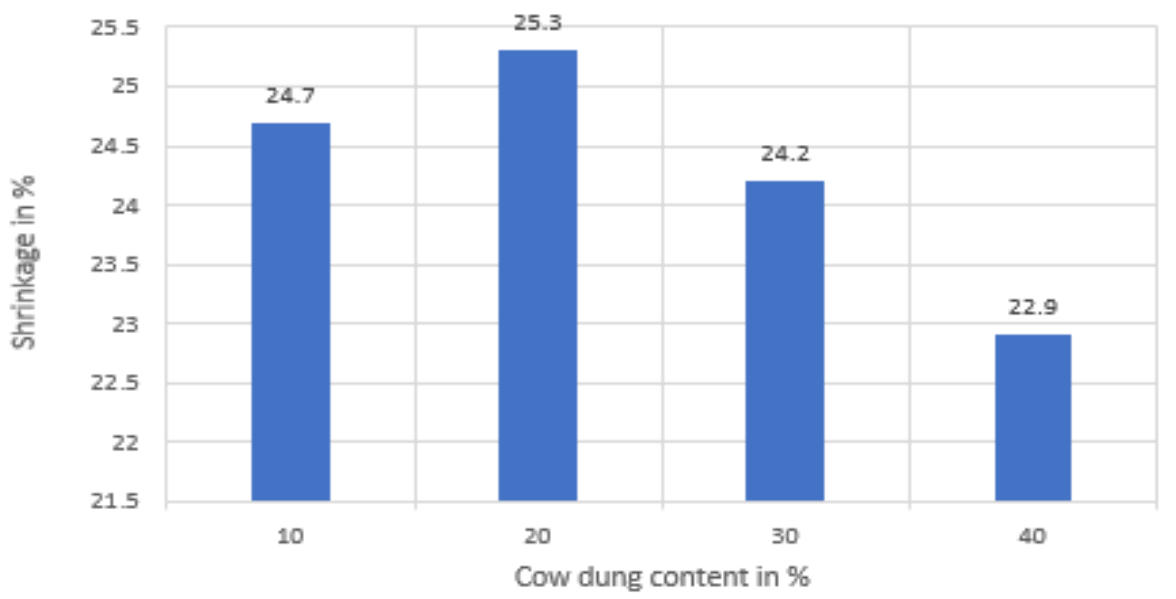

Figure 8: Shrinkage of cohesive soil mortar in function of cow dung content

Based on the results above, the mix ratio of $20 \%$ of cow dung and cohesive soil shows high shrinkage. The value is greater than the one for cement mortar and it is more liable to cracking (IS: 2250 - 1981). It can however be seen that the further addition of cow dung reduced the shrinkage, and therefore the positive influence of cow dung in cohesive soil mortar.

\subsection{The durability test}

The following Fig. 9 below shows how the plastered cohesive soil mortar mixed with the cow dung and cement mortar were looking like after 7 days respectively.

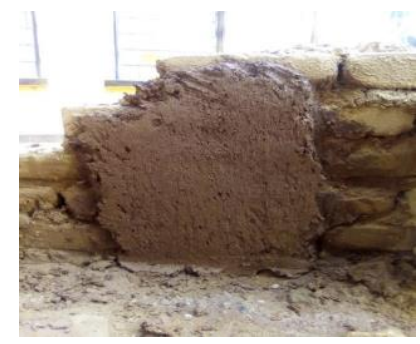

(a)

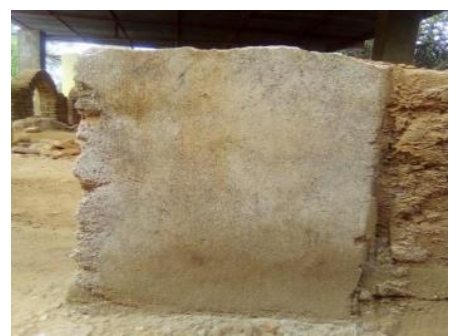

(b)

Figure 9: Plastered cohesive soil mortar mixed with the cow dung (a), and plastered cement mortar 
The visual test, after 7 days showed that the cohesive soil mortar mixed with cow dung plastered looked strong, comparing to the cement mortar, and it adhered well to the masonry wall. Therefore, referencing to ASTM C270 Standard Specification for Mortar for Unit Masonry, the proposed mortar of cohesive soil mixed with cow dung was suitable and, therefore it can be used in building activities especially in plastering works.

\section{CONCLUSIONS AND RECOMMENDATION}

The objective of this study was to assess the performance of soil mortar made using cohesive soils mixed with cow dung, and compare it with the ordinary Portland cement mortar to establish its suitability as finishing materials, with consideration of its affordability and its stability to the environment. The cohesive soil extracted from one of the local sites was sieved to extract organic matters, and then the Atterberg limits test was conducted to establish the cohesive status of the soils. The cow dung was mixed with the cohesive soil with different percentages: 10\%, 20\%, $30 \%, 40 \%$, to make respective cubes, which were kept for 3 days in water for the water absorption test. Later they were dried for 28 days in an open air space, before they were tested accordingly. The best water absorption for all cubes was found to be 19.82 in average which corresponded to $20 \%$ of cow dung content. The shrinkage of the cohesive soil mortar mixed with cow dung content from $10 \%$ to $20 \%$ showed an increase from 24.7 to $25.3 \%$; and then it decreased to 24.2 and $22.9 \%$ respectively at $30 \%$ and $40 \%$. The durability test was conducted visually and it showed that no cracks in plastered mortar and was well attached to the wall. As conclusion, the soil mortar mixed with cow dung could be used in construction activities especially in plastering process. The content of $20 \%$ of cow dung showed more good properties and higher durability, and therefore it could be considered as a low-cost alternative construction material to cement mortar for some structural members under normal conditions. In order to avoid the earlier shrinkage and cracks in mortar due to spontaneous drying by sun, this mortar should not be left in open area at least at earlier stage of seven days.

\section{References}

Adinkrah-appiah (2013), Improving the Structural Characteristics of Earth. International Journal of Science and Research, pp. 1119-1126.

Aman Kumar (2018), Partial Replacement Of Cement With Fly Ash And Cow Dung Ash By Using Quarry Dust As A Fine Aggregate; International Journal of Engineering Science Invention (IJESI), Volume 7 Issue 10 Ver II, PP 01-11,2018. 
ASTM C270 Standard Specification for Mortar for Unit Masonry

BS 1924-2:1990. Stabilized materials for civil engineering purposes. Methods of test for cementstabilized and lime-stabilized materials, October 1990

Burmister, 1949. Classified the plasticity index in a qualitative manner.

C Venkatasubramanian*, D Muthu, G Aswini, G Nandhini and K Muhilini (2012); Experimental studies on effect of cow dung ash (pozzolanic binder) and coconut fiber on strengthproperties of concrete; IOP Conf. Series: Earth and Environmental Science 80 (2017) 012012 doi :10.1088/1755-1315/80/1/012012.

D.P. Katale, V.S. Kamara and A.A. Adedeji (2014), Investigation on the Use of Clayey Soil Mixed with Cow Dung to Produce Sustainable Bricks; Trends in Applied Sciences Research, Volume 9 (8): 406-424, 2014

IS 2250 (1981): Code of Practice for Preparation and Use of Masonry Mortars

Kwadwo Adinkrah-Appiah, Evans Zoya Kpamma (2015), Improving the Structural Characteristics of Earth Blocks as an Input of Affordable Housing for Low-Income Northern Communities of Ghana; International Journal of Science and Research (IJSR) 4(9):4-438.

Ministry of Infrastructures, Basic Housing Construction Instructions for Protection Against Natural and Manmade Disasters in Rural Areas, Rwanda Housing Authority, 2012

Ministry of Infrastructures, National Housing Policy , Final Draft 17/03/2015

Peter Paa-Kofi Yalley and Dorothy Manu (2013), Strength and Durability Properties of Cow Dung Stabilised Earth Brick; Civil and Environmental Research, Vol.3, No.13, 2013

Okello Thomas, Prof. Oyawa Walter. Dr. Ajwang Patrick (2017); Use of Cow Dung and Local Brewery Waste as a Partial Replacement of Cement for Plastering Low Cost Houses. IOSR Journal of Mechanical and Civil Engineering (IOSR-JMCE) e-ISSN: 2278-1684,pISSN: 2320-334X, Volume 14, Issue 3 Ver. II (May. - June. 2017), PP 27-32.

P. Thej Kumar, R. Harshini Reddy and DVS Bhagavanulu (2015), A Study on the Replacement of Cement in Concrete By Using Cow Dung Ash; International Journal of Scientific Engineering and Applied Science (IJSEAS) - Volume-1, Issue-9, December 2015

Simango D.G. and Lyson A.A.B. (2005). Use of cowdung as a soil stabilizer for construction of Adobe. Malawi Journal of Science and Technology, Vol. 1 pp. 15-20

Sruthy B, Gibi Miriyam Mathew, Anisha G Krishnan, Sruthi G Raj (2017). An Experimental Investigation on Strength of Concrete Made with Cow Dung Ash and Glass Fibre; 
International Journal of Engineering Research \& Technology (IJERT), Vol. 6 Issue 03, March-2017.

Vasu.K (2019), experimental investigation on partial replacement of cement with cow dung ash; IJARIIE, Vol-5 Issue-3 2019.

Wagner, J.F. (2013): 9th chapter mechanical properties of clays and clay minerals in developments in clay Science, 2nd edition 2013, Elsevier Ltd., 813p 